Check for updates

Cite this: RSC Adv., 2019, 9, 15357

Received 5th March 2019

Accepted 7th May 2019

DOI: $10.1039 / \mathrm{c} 9 \mathrm{ra01659g}$

rsc.li/rsc-advances

\section{Biogenesis of ZnO nanoparticles using Pandanus odorifer leaf extract: anticancer and antimicrobial activities}

\author{
Afzal Hussain, a Mohammad Oves, ${ }^{b}$ Mohamed F. Alajmi, ${ }^{\star a}$ Iqbal Hussain, ${ }^{c}$ \\ Samira Amir, ${ }^{d}$ Jahangeer Ahmed, ${ }^{e}$ Md Tabish Rehman, ${ }^{a}$ Hesham R. El-Seedif \\ and Imran Ali (D)*gh
}

The continuously increasing incidence rates of cancer and infectious diseases are open threats to the sustainable survival of animals and humans. In the last two decades, the demands of nanomaterials as modern therapeutic agents have increased. In this study, biogenic zinc oxide nanoparticles (ZnO NPs) were developed from aqueous Pandanus odorifer leaf extract (POLE) and characterized using modern methods and tools, such as electron microscopy, X-ray diffraction, energy dispersive X-ray spectroscopy (EDX), Fourier transform infrared spectroscopy and UV-vis spectroscopy, which indicated the formation of very pure, spherical NPs approximately $90 \mathrm{~nm}$ in size. The anticancer activity of the ZnO NPs was evaluated by MTT and neutral red uptake (NRU) assays in MCF-7, HepG2 and A-549 cells at different doses $\left(1,2,5,10,25,50,100 \mu \mathrm{g} \mathrm{m}^{-1}\right)$. Moreover, the morphology of the treated cancer cells was examined by phase contrast microscopy. The results suggest that the synthesized ZnO NPs inhibited the growth of the cells when applied a concentration from 50-100 $\mu \mathrm{g} \mathrm{ml}^{-1}$. Moreover, the biogenic $\mathrm{ZnO}$ NPs were analysed as an antimicrobial agent against pathogenic bacteria. The highest antibacterial activity was observed against Gram-positive Bacillus subtilis (26 nm) and Gram-negative Escherichia coli $(24 \mathrm{~mm})$ at $50 \mu \mathrm{g}$ per well. Complete bacterial growth (100\%) vanished 100\% upon treatment with $\mathrm{ZnO}$ NPs at $85 \mu \mathrm{g} \mathrm{ml}^{-1}$. Overall, POLE mediated derived biogenic ZnO NPs could serve as a significant anticancer and antimicrobial agent and be used in the development of novel drugs and skin care products.

\section{Introduction}

Nanomaterials are extensively used in diverse fields, such as energy, food processing, agriculture, and innovative textile fabrication, as well as several biomedical applications (biosensors, nanomedicine, and bionanotechnology). ${ }^{1,2}$ It is known that nanoscale materials can be suitable agents for influencing the properties and functions of living and anthropogenic

${ }^{a}$ Department of Pharmacognosy, College of Pharmacy, King Saud University, Riyadh 11451, Kingdom of Saudi Arabia. E-mail: malajmii@ksu.edu.sa

${ }^{b}$ Center of Excellence in Environmental Studies, King Abdulaziz University, Jeddah, 21589, Kingdom of Saudi Arabia

'Department of General Studies, Jubail Industrial College, Jubail Industrial City, Jubail 31961, Kingdom of Saudi Arabia

${ }^{d}$ Department of Chemistry, College of Science \& General Studies, Alfaisal University, Riyadh 11451, Kingdom of Saudi Arabia

${ }^{e}$ Department of Chemistry, College of Science, King Saud University, Riyadh 11451, Kingdom of Saudi Arabia

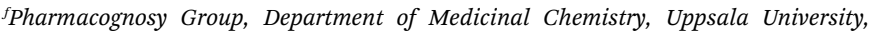
Biomedical Centre, Box 574, 75123 Uppsala, Sweden

${ }^{g}$ Department of Chemistry, College of Sciences, Taibah University, Al-Medina AlMunawara, 41477, Saudi Arabia. E-mail: drimran.chiral@gmail.com

${ }^{h}$ Department of Chemistry, Jamia Millia Islamia Central University, New Delhi, India systems. $^{3}$ Nanotechnology plays a vital role in nanomedicine because nano structures of different shapes exhibit new and considerably enhanced physicochemical and biological properties as well as distinct phenomena and functionalities. ${ }^{4}$ The intrinsic properties of metal and metal oxide nanoparticles (NPs) such as zinc oxide ( $\mathrm{ZnO})$, titanium dioxide $\left(\mathrm{TiO}_{2}\right)$, and silver are mostly characterized by the NP size, composition, crystallinity, and morphology. Reducing the size of a material to the nanoscale can modify its chemical, mechanical, electrical, structural, morphological, and optical properties. These changed features allow NPs to interact uniquely with cellular biomolecules and thus facilitate the physical transfer of NPs into intracellular structures. ${ }^{5,6}$ Among these NPs, ZnO NPs have gained tremendous interest due to their potential as chemotherapeutic and antimicrobial agents. ${ }^{7,8}$ Cancer is one of the main causes of human mortality worldwide, accounting for approximately 7.6 million deaths every year globally. It is estimated that the number of deaths may increase up to 11 million in 2030. Nearly, $70 \%$ of human deaths occur from cancerrelated disease in the poor or middle-income countries because of the limited availability of preventive on, diagnostic, and therapeutic resources. ${ }^{9-12}$ In current reports of WHO cancer is responsible for apparently 9.6 million deaths in 2018 and 
about one in six deaths was happened due to cancer. Cancer is now the second leading cause of human death worldwide [https:/www.who.int/news-room/fact-sheets/detail/cancer].

Surgical procedures are effective when the cancer is localized, although adjuvant chemotherapy is still needed. Radiotherapy plays a significant role in cancer treatment, provided that the cancer is not disseminated. Currently, many medications are being used alone or in combination with others, with the most useful medicines including cisplatin, carboplatin, bleomycin, 5-fluorouracil, doxorubicin, dactinomycin, 6mercaptopurine, tamoxifen, taxol, topotecan, vinblastine, and etoposide, ${ }^{13}$ all of which are organically synthesized and extracted from plants. However, many anticancer agents are non-specific, resulting in elusive mechanisms of action, narrow spectra of activity, severe side effects (nausea, ear damage, vomiting, nephrotoxicity) and inherent or acquired resistance; these effects limit their successful clinical use. ${ }^{14}$ ZnO NPs have been effective in having minimal side effects and targeted action on cancer cells due to the large surface area of the NPs. ${ }^{15-17}$ At physiological pH, ZnO NPs are highly selective for cancer cells, resulting in the generation of active oxide, hydrogen peroxide $\left(\mathrm{H}_{2} \mathrm{O}_{2}\right)$ and superoxide from their surface, which may be a source of cytotoxicity in cancer cells. ${ }^{18-20}$

Another important aspect with more acceptance is the development of nanomaterials with antimicrobial properties to overcome the phenomenon of multidrug resistance. Multidrug resistance in bacteria is a serious health issue associated with enormous social and economic burdens. ${ }^{21}$ The emergence of a new persistent bacterial strain is the direct consequence of the non-judicial use of antibiotics. ${ }^{22}$ The risk of infection with pathogenic strains is increasing due to the lack of proper medication systems and sterilization techniques and the improper handling and treatment of hazardous materials. ${ }^{23}$ For example, infections by Shigella flexneri cause 1.5 million deaths annually due to the contamination of food and drinks. ${ }^{24}$ Other bacterial species that contribute to antibiotic resistance include Escherichia coli 0157:H, Campylobacter jejuni, Staphylococcus aureus, Pseudomonas aeruginosa, Enterococcus faecalis, Salmonella strains, and Clostridium perfringens. Recently, some nanomaterials have been employed as antimicrobial agents to prevent infection with pathogenic microbes. In this regard, $\mathrm{ZnO}$ NPs have the potential to exert their antimicrobial activity by rupturing the cell wall of microorganisms through the generation of $\mathrm{Zn}^{2+}$ and reactive oxygen species (ROS). ${ }^{25-27}$

To overcome both life-threatening issues, the development of NP-based drugs has become in great demand to cure cancer and fight bacteria. Conventional methods for the synthesis of NPs include microwave decomposition, ${ }^{28}$ simple wet chemistry routes, ${ }^{29}$ deposition processes, simple precipitation methods, ${ }^{30}$ hydrothermal synthesis, ${ }^{31}$ solvothermal methods, ${ }^{32}$ microwave hydrothermal methods, ${ }^{33}$ and hydrothermal techniques. ${ }^{34}$ However, these physiochemical methods are expensive, time and energy consuming and generate multiple hazardous chemicals by-products. Thus, there is a need for a "green chemistry" approach to NP synthesis that includes clean, nontoxic and environmentally friendly methods that can be applied in the ambient atmosphere. NPs synthesized via green synthetic routes are highly water-soluble, biocompatible and less toxic. Plant extracts are a very promising tool for the facile green synthesis of NPs. Citrus aurantifolia fruit juice, Parthenium hysterophorus leaf extracts, and Aloe species extracts have been used in the synthesis of ZnO NPs. ${ }^{35-37}$ Pandanus odorifer (Forssk.) Kuntze (synonym Pandanus odoratissimus Linn., Family: Pandanaceae) is a traditional Indian Ayurvedic medicine widely used for the treatment of headache, rheumatism, cold/flu, epilepsy, leucoderma, ulcers, hepatitis, smallpox, leprosy, syphilis, and even cancer. It also acts as a cardiotonic, antioxidant, dysuric, an aphrodisiac. The phytochemical analysis shows that it is a rich source of phytochemicals, such as lignans and isoflavones, coumestrol, alkaloids, steroids, carbohydrates, phenolic compounds, glycosides, proteins, amino acids, and vitamins, in addition to other nutrients. ${ }^{38} \mathrm{We}$ have reported the synthesis of ZnO NPs using Pandanus odorifer leaf water extract (POLE), as a bio-template that never been reported. Like many plants, Pandanus odorifer leaf extract contains high levels of flavonoids and phenols. The quantified data of flavonoids/phenolic components present in the leaf extract of Pandanus odorifer has been given in the manuscript under the section phytochemical analysis of the plant extract. Moreover, the presence of hydroxyl and ketonic groups has been confirmed by FTIR analysis. It is a well-established fact that these functionally active components act as reducing as well as a stabilizing agent during the biosynthesis of metal-based nanoparticles. Recent studies have discovered that plant metabolites such as sugars, terpenoids, phenolic, alkaloids, phenolic acids, and proteins play a significant role in the reduction of metal ions into nanoparticles and in providing stability to nanoparticles. Moreover, the reducing power of a plant extract cannot be solely determined by a single bioactive component. Rather, it is the synergistic effect of all the bioactive components present in the plant extract to reduce a metal into nanoparticle. ${ }^{39-41}$ Previously we had reported the contents of Pandanus odorifer leaf extract (i.e. phenolic and flavonoid) that could trigger the nucleation and size of the nanoparticles. ${ }^{42}$

The synthesized ZnO NPs were characterized using modern techniques, such as X-ray diffraction (XRD), scanning electron microscopy (SEM), energy dispersive X-ray spectroscopy (EDX), Fourier transform infrared (FTIR) spectroscopy and UV-vis spectroscopy. The physical and morphological examinations of the ZnO NPs show the spherical structure. The well-defined nanocrystals were tested as an anticancer agent against MCF-7 (breast cancer), HepG2 (liver cancer), and A549 (human lung alveolar epithelial) cells. Simultaneously, these newly synthesized ZnO NPs were also used as an antimicrobial agent against Gram-positive (B. subtilis) and Gram-negative (E. coli) bacteria.

\section{Experimental}

\subsection{Materials and reagents}

Zinc acetate dihydrate $\left\{\mathrm{Zn}\left(\mathrm{CH}_{3} \mathrm{COO}\right)_{2} \cdot 2 \mathrm{H}_{2} \mathrm{O}\right\}$ was procured from Sigma Aldrich (USA). Bacterial culture media were purchased from HiMedia (Pvt. Ltd. Mumbai, India). Antibiotic/ antimycotic solution, Dulbecco's Modified Eagle Medium (DMEM) and fetal bovine serum were procured from Invitrogen, 
Life Technologies, USA. Glassware and plastic consumables were obtained from Nunc, Denmark.

\subsection{High pressurized solvent extraction (HPSE) for preparation of leaf extract}

Pandanus odorifer plant leaves were collected from mature plants grown in the botanical garden of Aligarh Muslim University, Aligarh, U.P., India. For the preparation of the POLE, a specific speed extractor (Buchi, E-914, Germany) was used. The extraction cells were prepared by inserting a cellulose filter and metal frit at the bottom of each $10 \mathrm{ml}$ stainless steel cell to prevent entering particles to the solvent lines and collection vials. Briefly, $5 \mathrm{~g}$ of freshly collected Pandanus odorifer leaves was cleaned, washed three times with ultrapure water, and further eroded by $70 \%$ ethanol in water to remove microorganisms contaminating the leaf surface. These leaves were cut into small pieces, dried in an oven at $50{ }^{\circ} \mathrm{C}$ overnight, and crushed into a fine powder. This powder was placed in the cell of the speed extractor, which was programmed to run for two cycles. Each cycle was fixed at $42 \mathrm{~min}$, and the temperature was set at $50{ }^{\circ} \mathrm{C}$. Initially, $100 \mathrm{ml}$ of water was filtered, and concentrated water extract was obtained. ${ }^{43}$ This POLE was collected in tubes and stored at $4{ }^{\circ} \mathrm{C}$.

\subsection{Phytochemical analysis of the plant extract}

Phytochemical analysis was conducted to identify the total phenolic and flavonoid contents of the POLE. The total phenolic content was estimated using a standard gallic acid curve, as previously described..$^{44}$ Briefly, leaf extract $(0.125 \mathrm{ml})$ was mixed with $0.5 \mathrm{ml}$ of deionized water followed by the addition of $0.125 \mathrm{ml}$ of Folin-Ciocalteu reagent and incubation for $5 \mathrm{~min}$ at room temperature. Then, $1.25 \mathrm{ml}$ of $\mathrm{Na}_{2} \mathrm{CO}_{3}(7 \%)$ solution was added to the above mixture and made up to $3 \mathrm{ml}$ with deionized water, and followed by incubation for $1.5 \mathrm{~h}$ at room temperature. The maximum absorption at $760 \mathrm{~nm}$ was monitored. The total flavonoid content was analysed using a standard quercetin curve, as previously described. ${ }^{45}$ Briefly, $0.5 \mathrm{ml}$ of $\mathrm{AlCl}_{3}(2 \%$ in methanol) was mixed well with $0.5 \mathrm{ml}$ of POLE and incubated for $10 \mathrm{~min}$ at room temperature; then absorbance at $368 \mathrm{~nm}$ was recorded.

\subsection{Biogenesis of $\mathrm{ZnO}$ NPs}

To prepare a reaction solution, $50 \mathrm{ml}$ of $20 \mathrm{mM}$ zinc acetate solution was added dropwise to $20 \mathrm{ml}$ of POLE under constant stirring at $80{ }^{\circ} \mathrm{C}$ for $3 \mathrm{~h}$. The reaction mixture became dark brown, and a brown precipitate developed. For further precipitation, the reaction mixture was kept overnight to allow complete reaction. The precipitate was obtained by centrifugation at $15000 \mathrm{rpm}$ for $10 \mathrm{~min}$ at room temperature $\left(25^{\circ} \mathrm{C}\right)$. The precipitate (containing zinc compound) was washed several times with ultrapure Milli-Q water to remove the unwanted biological and chemical moieties and then ovendried at $70{ }^{\circ} \mathrm{C}$ for $24 \mathrm{~h}$. Finally, the samples were calcined at various temperatures $\left(400\right.$ and $\left.600{ }^{\circ} \mathrm{C}\right)$ for $3 \mathrm{~h}$ before characterization.

\subsection{Biophysical characterization of ZnO NPs}

The phase purity of the ZnO NPs was characterized by XRD using a Phillips-PW 1729 X-ray diffractometer (Holland) with $\mathrm{Cu}$ radiation $(1.54430 \AA)$. The XRD patterns were recorded with a step size of $0.02^{\circ}$ and a scan speed of $2^{\circ} \mathrm{min}^{-1}$ ranging from $30^{\circ}$ to $80^{\circ}$ of $2 \theta$. The surface morphology of the resulting $\mathrm{ZnO}$ NPs was characterized by field emission scanning electron microscopy (FESEM) using a MIRA II LMH system. The UV-vis absorption spectrum of the ZnO NPs was recorded in the range of $300-800 \mathrm{~nm}$ using a UV-visible spectrophotometer (Evolution 201, Thermo Fisher Scientific). Distilled water was used as a reference. The involvement of organic functional groups in the nanomaterial formation was analysed by FTIR spectrometry (PerkinElmer), and the spectra of the product were recorded in the range of $4000-400 \mathrm{~cm}^{-1}$.

\subsection{Anticancer activity and cell morphology}

2.6.1 Cell culture. The MCF-7 (breast cancer), HepG2 (liver cancer), and A-549 (lung cancer) cells were used to determine the cell viability against ZnO NPs exposure. The MCF-7, HepG2, and A-549 cells were obtained from American Type Culture Collection (ATCC) (Manassas, VA) USA. MCF-7, HepG2, and A549 cells were cultured in DMEM in the presence of foetal bovine serum (10\%), sodium bicarbonate $(0.2 \%)$, and antibiotic/antimycotic solution $(1 \mathrm{ml} / 100 \mathrm{ml}$ of medium). The cells were maintained in a $5 \% \mathrm{CO}_{2}$ and $95 \%$ atmosphere under high humidity at $37^{\circ} \mathrm{C}$. Each cell culture was assessed for viability by trypan blue dye exclusion assay, ${ }^{46}$ and batches showing $>98 \%$ cell viability were used in this study. MCF-7, HepG2, and A-549 cells were treated with varying concentrations $\left(1-100 \mu \mathrm{g} \mathrm{ml}^{-1}\right)$ of biogenic ZnO NPs. Each treated cell culture was deliberated used for cytotoxicity assays (MTT and NRU) or the morphology analysis.

2.6.2 MTT assay for cytotoxicity. MTT $\{3-(4,5-$ dimethylthiazol-2-yl)-2,5-diphenyl tetrazolium bromide\} reagent was used to evaluate cell viability. ${ }^{47}$ Briefly, from each treated cell culture, approximately $1 \times 10^{4}$ cells were allowed to incubate in a $\mathrm{CO}_{2}$ chamber for $24 \mathrm{~h}$ at $37^{\circ} \mathrm{C}$ in 96-well culture plates. Various doses of ZnO NPs (1-100 $\mu \mathrm{g} \mathrm{ml}^{-1}$ ) were used to treat the cancer cells. After nanomaterial exposure, $10 \mu \mathrm{l}$ per well MTT (reagent $5 \mathrm{mg} \mathrm{ml}^{-1}$ of stock in PBS) was added to 100 $\mu \mathrm{l}$ of cell suspension, and the plate was incubated for $4 \mathrm{~h}$. Then, the supernatant was discarded, and $200 \mu \mathrm{l}$ of DMSO was added to each well and mixed gently. The absorbance at $550 \mathrm{~nm}$ of the plates were maintained on a rocking shaker for $10 \mathrm{~min}$ at room temperature; the developed color was recorded using a multiwell microplate reader (Multiskan Ex, Thermo Fisher Scientific, Finland). Identical conditions were used for the untreated cell that served as the controls.

2.6.3 Neutral red uptake (NRU) assay for cytotoxicity. The assessment of cytotoxicity by NRU assay was performed as previously described. ${ }^{48}$ After the treatment with ZnO NPs, the medium was extracted, and the cells were washed three times with PBS. The treated and washed cells were cultured in DMEM supplemented with NR $\left(50 \mu \mathrm{g} \mathrm{ml}^{-1}\right)$ and incubated for $3 \mathrm{~h}$. Then, the medium was washed off rapidly with a solution 
containing $1 \%$ calcium chloride and $0.5 \%$ formaldehyde, and the cells were exposed to a mixture of ethanol (50\%) and acetic acid $(1 \%)$ for $20 \mathrm{~min}$ at $37{ }^{\circ} \mathrm{C}$ for dye extraction. The at $550 \mathrm{~nm}$ was measured, and the experimental values obtained were compared with the control values of the culture plate.

2.6.4 Morphological examination of cells by phase-contrast microscopy. After treatment, morphological changes in the cellular structure were analysed. In this study, alterations in the (MCF-7, HepG2, and A-549) cellular structure were induced by ZnO NPs. Each type of cell was exposed to different concentrations (1-100 $\mu \mathrm{g} \mathrm{ml}^{-1}$ ) of ZnO NPs. After washing cells from each treatment group were observed using an inverted phasecontrast microscope at a magnification of $20 \times$.

2.6.5 Cancer cell cytotoxicity analysis by flow cytometry. The death of MCF-7, HepG2, and A549 cancer cells was examined by double staining with Annexin V-FITC and propidium iodide (PI) according to the manufacturer's instructions. ${ }^{49}$ Both the Annexin V-FITC and PI kits were procured from Molecular Probe (Eugene, USA). Briefly, $1 \times 10^{6}$ cells per $\mathrm{ml}$ were exposed to ZnO NPs $\left(100 \mu \mathrm{g} \mathrm{ml}{ }^{-1}\right)$ for $48 \mathrm{~h}$ in 6-well plates under optimum conditions in a $\mathrm{CO}_{2}$ incubator. At the end of the specific period of exposure, the cells were trypsinized, washed with cold PBS and centrifuged at $1000 \mathrm{rpm}$ for $10 \mathrm{~min}$ at $4{ }^{\circ} \mathrm{C}$. The cell pellet was washed with PBS and re-suspended in $100 \mu \mathrm{l}$ of $1 \times$ binding buffer $\left(1 \times 10^{6}\right.$ cells per $\left.\mathrm{ml}\right)$. Then, $5 \mu \mathrm{l}$ of Annexin V-FITC and PI reagent was added to each cell suspension, and the cells were gently vortexed. Subsequently, the cells were incubated for $20 \mathrm{~min}$ at $25{ }^{\circ} \mathrm{C}$ in the dark. Each sample was then diluted by the addition of $400 \mu \mathrm{l}$ of $1 \times$ binding buffer and examined. The fluorescence emission from the Annexin- $V$ and PI-stained cells was measured at 530-575 nm using a flow cytometer (MACS Quant, Germany). Finally, each treated sample was subjected to flow cytometry on a FACS Calibur system and the data were analysed using BD Cell Quest ${ }^{\mathrm{TM}}$ Pro software (version 5.2). According to the software, the cells are represented as follows: lower right quadrant, early apoptotic cells $\left(\mathrm{FITC}^{+} / \mathrm{PI}^{-}\right)$; lower left quadrant, normal cells $\left(\mathrm{FITC}^{-} / \mathrm{PI}^{-}\right)$; upper right quadrant, late apoptotic cells $\left(\mathrm{FITC}^{+} / \mathrm{PI}^{+}\right)$; upper left quadrant, necrotic cells (FITC ${ }^{-} / \mathrm{PI}^{+}$).

\subsection{Antibacterial activity}

2.7.1 Bacterial cell viability in the presence of ZnO NPs. The antibacterial activity of the green synthesized ZnO NPs against Gram-positive, and Gram-negative bacteria was determined using Bacillus subtilis: LN827668.1 and, E. coli: LN835288.1 respectively. Both the bacteria B. subtilis and E. coli were procured from the library of culture collection of the King Fahad Medical Research Center (KFMRC) at King Abdulaziz University, Jeddah, Saudi Arabia. The Gram-negative E. coli and the Gram-positive B. subtilis were grown in nutrient broth (HiMedia, Pvt., Ltd., Mumbai, India) under the optimum conditions with shaking in an incubator for overnight. Bacterial growth was measured by culture turbidity as a qualitative measurement and further confirmed by plate culture testing to determine the viability in the presence and absence of ZnO NPs. To determine the bacterial growth rate in the presence of the
ZnO NPs, various $\left(10,20,40,60,80\right.$ and $\left.100 \mu \mathrm{g} \mathrm{ml}^{-1}\right)$ doses were added to the liquid medium and incubated with the bacteria at $37{ }^{\circ} \mathrm{C}$. Cultures of both bacteria without NPs were incubated in the same medium under the optimum growth conditions as a control. The same concentrations of NPs in separate media without bacteria were used as blank controls to account for optical interference by the light-scattering properties of the NPs. An overnight primary bacterial culture $(1 \mathrm{ml})$ was used to inoculate $100 \mathrm{ml}$ of nutrient broth (secondary culture) with different concentrations of ZnO NPs. The culture was incubated at $37^{\circ} \mathrm{C}$, and the optical density was monitored every hour with UV-vis spectrophotometer (Evolution 201, Thermo Fisher Scientific). Culture $(0.1 \mathrm{ml})$ from each flask treated was spread on the media surface and incubated for $16 \mathrm{~h}$. The number of colonies that appeared was counted as an indicator of the number of bacteria. These data were used to define the minimum inhibitory concentration and maximum bactericidal concentration of applied the ZnO NPs.

2.7.2 Antibacterial activity of ZnO NPs determined by zone inhibition assay. In this study, the antibacterial properties of the biogenic ZnO NPs against B. subtilis and E. coli were examined. A fresh culture of both bacterial strains was grown in nutrient broth overnight at $35{ }^{\circ} \mathrm{C}$ on an orbital shaker at $120 \mathrm{rpm}$. Nutrient agar plates were also prepared separately. These plates were inoculated separately with fresh culture (100 $\mu l)$ of $B$. subtilis and $E$. coli by the spread plate method. Furthermore, an $8 \mathrm{~mm}$ well was prepared on these inoculated plates using a sterilized steel borer, and each well base was sealed by molten agar to prevent surface leakage of the loaded material. Each well was filled with $100 \mu \mathrm{g}$ of the biogenic $\mathrm{ZnO}$ NP suspension and incubated overnight, and zone formation around the loaded material was observed.

2.7.3 ZnO NP effect on bacterial cell morphology. The cellular morphology of both bacterial strains was determined before and after treatment by SEM. After treatment with different concentrations of ZnO NPs, bacterial cells were fixed with primary fixative reagents (glutaraldehyde $2.5 \%$, paraformaldehyde $0.1 \mathrm{ml} \mathrm{l}^{-1}$ in sodium cacodylate buffer) and incubated for $1 \mathrm{~h}$ at $4{ }^{\circ} \mathrm{C}$. After incubation, the bacterial samples were centrifuged for $5 \mathrm{~min}$ at $1000 \mathrm{rpm}$ and washed thrice with ultrapure water (Milli Q). Furthermore, the samples were dehydrated with increasing concentrations of ethanol $10 \%$, $20 \%, 30 \%, 40 \%, 50 \%, 75 \%$, and $100 \%$ ) in water. These dehydrated bacterial cell samples were dried in a vacuum oven below $50{ }^{\circ} \mathrm{C}$. The dried materials were mounted on SEM stubs with a thin layer of carbon tape, followed by sputter-coating (Turbo Sputter Coater (K575X) Emitech, Kent, UK). Then, the stubmounted samples were observed at low voltage by SEM (JEOL, Ltd., Tokyo, Japan).

\subsection{Statistical analysis}

In this study, each result is expressed as the mean \pm standard error of triplicate independent experiments. Differences with $p$ $<0.05$ were considered statistically significant. Statistical analysis was performed by one-way ANOVA with Dunnett's post hoc test to compare values between the control and treated groups. 


\section{Results and discussion}

\subsection{Quantification of flavonoids and phenols and preparation of ZnO NPs}

Plant leaves are a rich source of flavonoids and phenolic components that have the potential to trigger the reduction of $\mathrm{Zn}^{2+}$ and control the size of synthesized ZnO NPs. Here, we prepared an aqueous extract of $P$. odorifer leaves and quantified its flavonoids and phenolic components. It was observed that $0.105 \%$ of phenols $(\mathrm{w} / \mathrm{w})$ and $0.035 \%$ of flavonoids $(\mathrm{w} / \mathrm{w})$ were present in POLE. Free hydroxyl and carboxylic groups of the flavonoids or phenols present in the plant extract bind to the surface of $\mathrm{Zn}^{2+}$ and trigger the formation of $\mathrm{ZnO}$ NPs, while the $\mathrm{C}=\mathrm{O}, \mathrm{C}=\mathrm{O}-\mathrm{C}$ and $\mathrm{C}=\mathrm{C}$ groups of heterocyclic compounds may act as a stabilizer. ${ }^{50,51}$ The concentration of the plant extract plays an essential role in the synthesis of stable ZnO NPs. In this study, we optimized the ratio of plant extract to zinc acetate at $50 \mathrm{ml}$ of zinc acetate solution $(20 \mathrm{mM})$ to $20 \mathrm{ml}$ of the leaf extract $(50 \mathrm{mg}$ $\mathrm{ml}^{-1}$ ) for the preparation of ZnO NPs. The resulting solution turned a dark brown. ZnO NPs were also synthesized using 5$15 \mathrm{ml}$ of the leaf extract. However, the resulting yield of ZnO NPs obtained was much lower. This might be due to insufficient quality of flavonoids and phenolic components present in 5$15 \mathrm{ml}$ of the leaf extract to completely reduce the zinc acetate solution (20 mM) into ZnO NPs (data not shown). Furthermore, the quality of flavonoids and phenolic components present in $20 \mathrm{ml}$ or more of the plant extract was sufficient to reduce all $\mathrm{Zn}^{2+}$ ions in the reaction mixture using a hot plate with continuous stirring at $80^{\circ} \mathrm{C}$. In this study, we cost-effectively synthesised ZnO NPs via a green synthesised route with reduce chemical toxicity.

\subsection{Characterization of ZnO NPs}

The XRD patterns of the dried precursor (template hybrids) at room temperature and the sintered $\mathrm{ZnO}$ product at various temperatures were determined and are shown in Fig. 1a. The
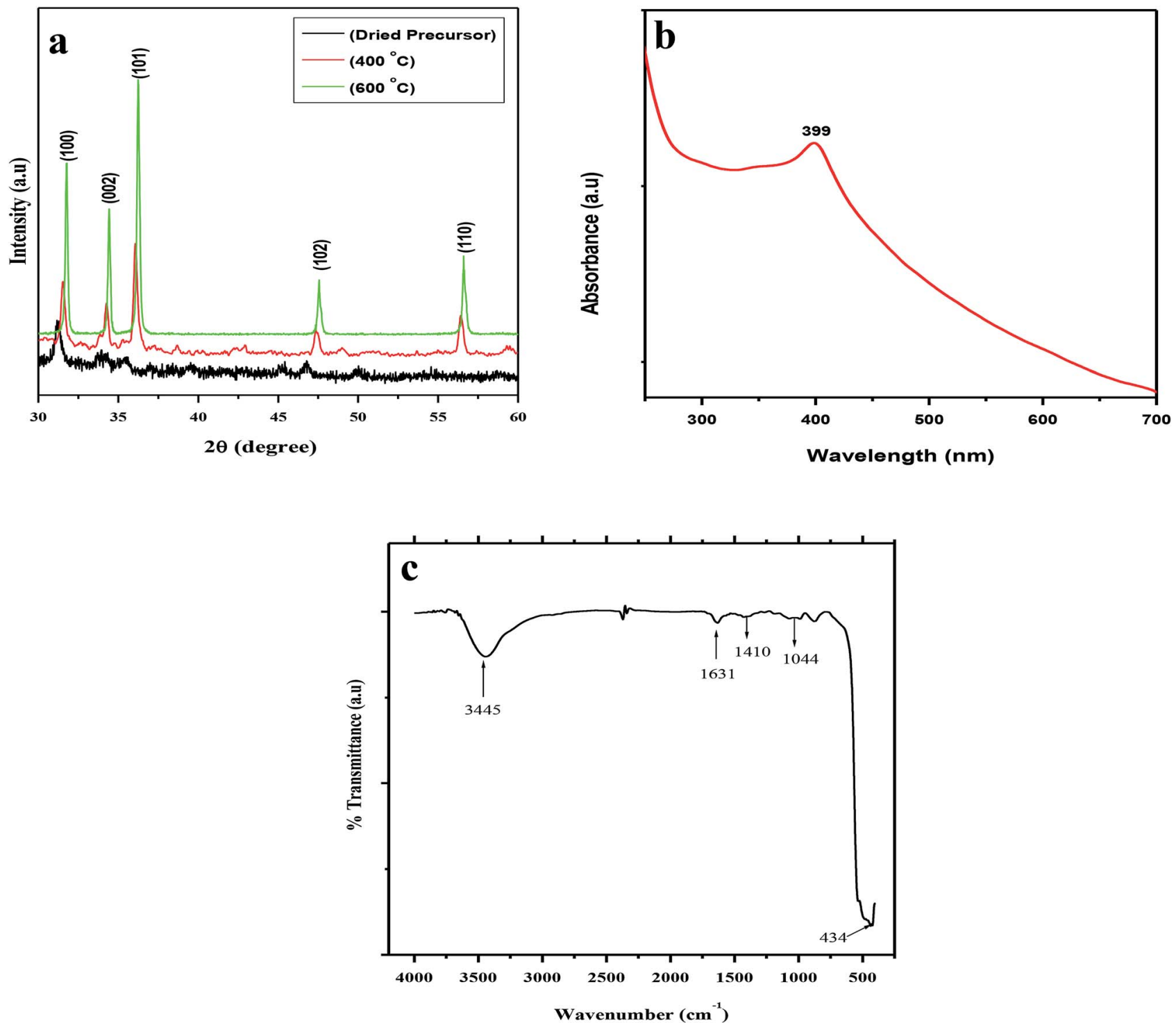

Fig. 1 (a) Typical X-ray diffraction (XRD) patterns of biogenic precursor and biogenic ZnO NPs after calcination at $400{ }^{\circ} \mathrm{C}$ and $600{ }^{\circ} \mathrm{C}$. (b) UV-vis spectrum of biogenic ZnO NPs after calcination at $600^{\circ} \mathrm{C}$. (c) FTIR spectrum of biogenic ZnO NPs after calcination at $600{ }^{\circ} \mathrm{C}$. 
XRD patterns were very well matched with JCPDS, 36-1451, indicating that all the diffraction peaks of the sintered samples showed the monophasic zincite structure of ZnO NPs. The XRD patterns demonstrate $2 \theta$ values at $31.74^{\circ}, 34.38^{\circ}, 36.22^{\circ}, 47.50^{\circ}$, and $56.54^{\circ}$ which corresponded to the crystal planes, i.e., (100), (002), (101), (102), and (110), thus confirming the presence of $\mathrm{ZnO}$. Most of the peaks belong to the single phase of $\mathrm{ZnO}$ and impurity peaks were not observed, which indicates the high purity of the ZnO NPs. This indicates the crystalline nature of synthesized nanoparticle which was in agreement with the earlier reports using Plectranthus Amboinicus leaf extract synthesis of ZnO NPs. ${ }^{52}$ Our results are comparable to Ishwarya et $a l .{ }^{53}$ reported the synthesis of $\mathrm{ZnO}$ nanoparticles using Ulva lactuca seaweed extract and, Narendhran et al., ${ }^{54}$ who fabricated zinc nanoparticles using the Lantana aculeate leaf extract, while Vanathi et al., ${ }^{55}$ synthesized the nanoparticles using Eichorrnia crassipes leaf extract.

The dried precursor was mainly amorphous because of the biological functional groups as organic components. The existence of weak $\mathrm{ZnO}$ peaks indicates that little crystalline $\mathrm{ZnO}$ is formed in the solution at room temperature. After calcination of the precursor at $400{ }^{\circ} \mathrm{C}$, there is evident crystallization. The calcination process occurs at $500{ }^{\circ} \mathrm{C}$, and as the intensities of the main peaks are enhanced, new patterns of diffraction peaks appear. The diffraction peaks become sharper with an increase in the calcination temperature to $600{ }^{\circ} \mathrm{C}$, suggesting that the integrity of the crystalline structure increased. No characteristic peaks of any impurities were detected, which demonstrates that the product has a high phase purity.

UV-vis spectroscopy is a widely used technique to characterize the optical properties of synthesized NPs. Fig. 1b represents the UV-vis absorption spectra of the biosynthesized spherical ZnO NPs at room temperature. The characteristic absorption spectrum of $\mathrm{ZnO}$ shows a well-defined exciton band at $\sim 399 \mathrm{~nm}$ (calculated band gap of $\sim 3.10 \mathrm{eV}$ ), which is very close to the bulk exciton absorption of $\mathrm{ZnO}(373 \mathrm{~nm}) \cdot{ }^{56,57}$ Due to the presence of a broad peak in the UV-vis spectra, the grown ZnO NPs showed excellent optical properties. In this study, the appearance of a single peak at approximately $399 \mathrm{~nm}$ indicated the formation of spherical ZnO NPs $\sim 90 \mathrm{~nm}$ in size.

The FTIR spectra further supported the formation of $\mathrm{ZnO}$ NPs using aqueous POLE and calcination at $600{ }^{\circ} \mathrm{C}$. The FTIR spectra of the spherical ZnO NPs biosynthesized with the help of POLE are presented in Fig. 1c. The spectra show a very broad and intense band at $3445 \mathrm{~cm}^{-1}$ associated with the stretching vibration of the $-\mathrm{OH}$ (hydroxyl) and $-\mathrm{NH}$ (amine) groups of POLE. The characteristic peak at $1631 \mathrm{~cm}^{-1}$ can be attributed to the $\mathrm{C}=\mathrm{O}$ (carbonyl) groups. The absorption band at $1410 \mathrm{~cm}^{-1}$ and $1044 \mathrm{~cm}^{-1}$ could be attributed $\mathrm{C}-\mathrm{C}$ and $\mathrm{C}-\mathrm{N}$ stretching respectively. The strong absorption band at $434 \mathrm{~cm}^{-1}$ is characteristic of ZnO NPs. ${ }^{52,58} P$. odorifer extract was also considered as the capping ligands, which give stability to the nanoparticles. ${ }^{42}$

Fig. 2a shows a FESEM image of the calcined ZnO NPs. The diameter of the spherical $\mathrm{ZnO}$ nanocrystals was $\sim 90 \mathrm{~nm}$, as determined by FESEM. The elemental composition of the $\mathrm{ZnO}$ nanocrystals was investigated using EDX. The EDX plot as shown in Fig. $2 \mathrm{~b}$ depicts the peaks of $\mathrm{Zn}$ and $\mathrm{O}$ for the $\mathrm{ZnO}$ calcined at $600{ }^{\circ} \mathrm{C}$, which indicates that the $\mathrm{ZnO}$ structures are a combination of only $\mathrm{Zn}$ and $\mathrm{O}$, as shown in Fig. 2b. No evidence of other impurities was found, which also confirms the high purity of the $\mathrm{ZnO}$ nanocrystals.

\subsection{Anticancer activity of biosynthesized ZnO NPs}

3.3.1 MTT assay and cellular morphology. MCF-7, HepG2, and A-549 cells were exposed to the biosynthesized ZnO NPs for a period of $24 \mathrm{~h}$, and the morphological changes were observed (Fig. 3). The cancer cells were treated with 1-100 $\mu \mathrm{g} \mathrm{ml}^{-1}$ of $\mathrm{ZnO}$ NPs, and the cell proliferation was examined using an inverted
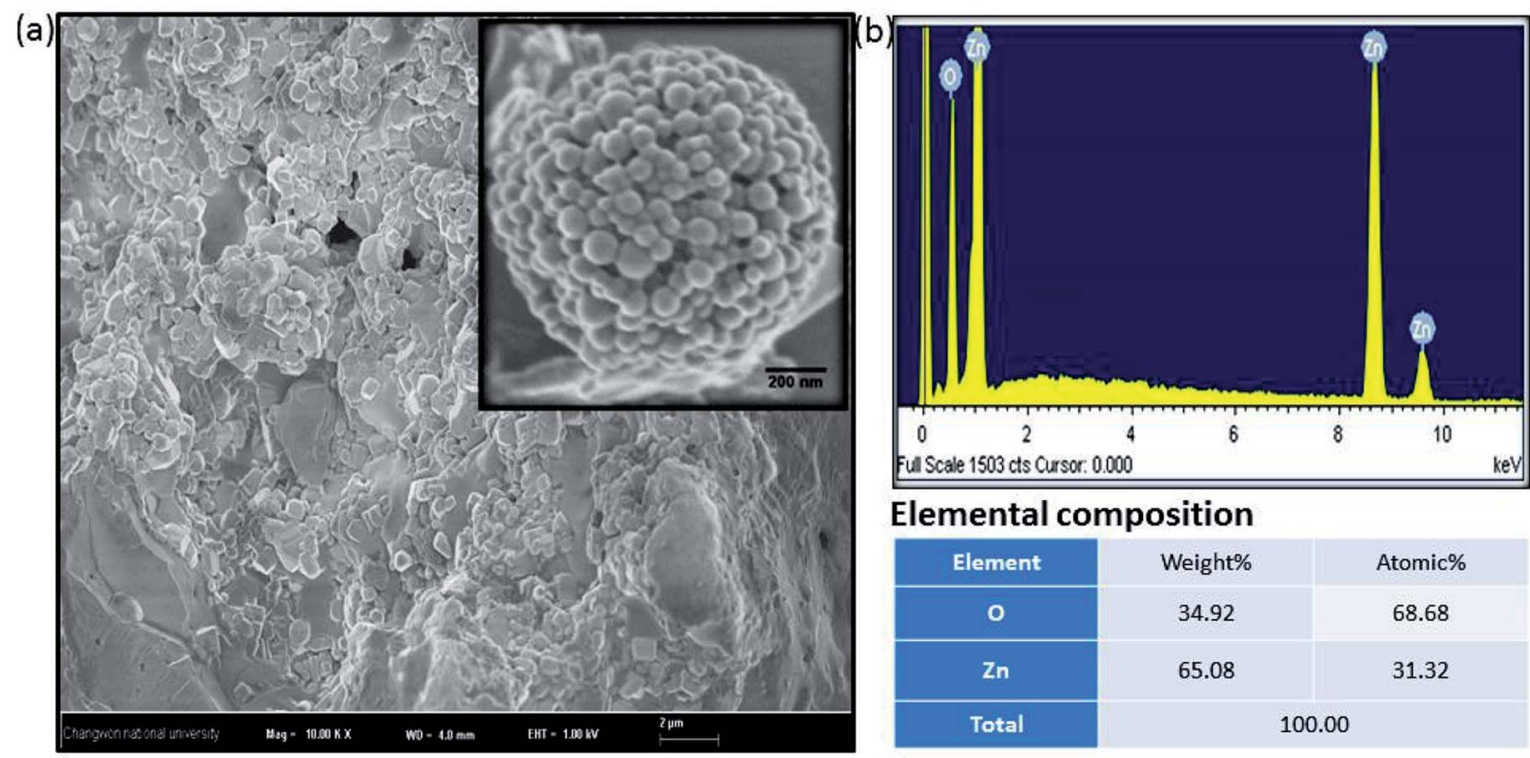

Fig. 2 Amorphous biogenic ZnO materials (a) FESEM image with high magnification (b) their corresponding EDX spectrum with elemental composition. 


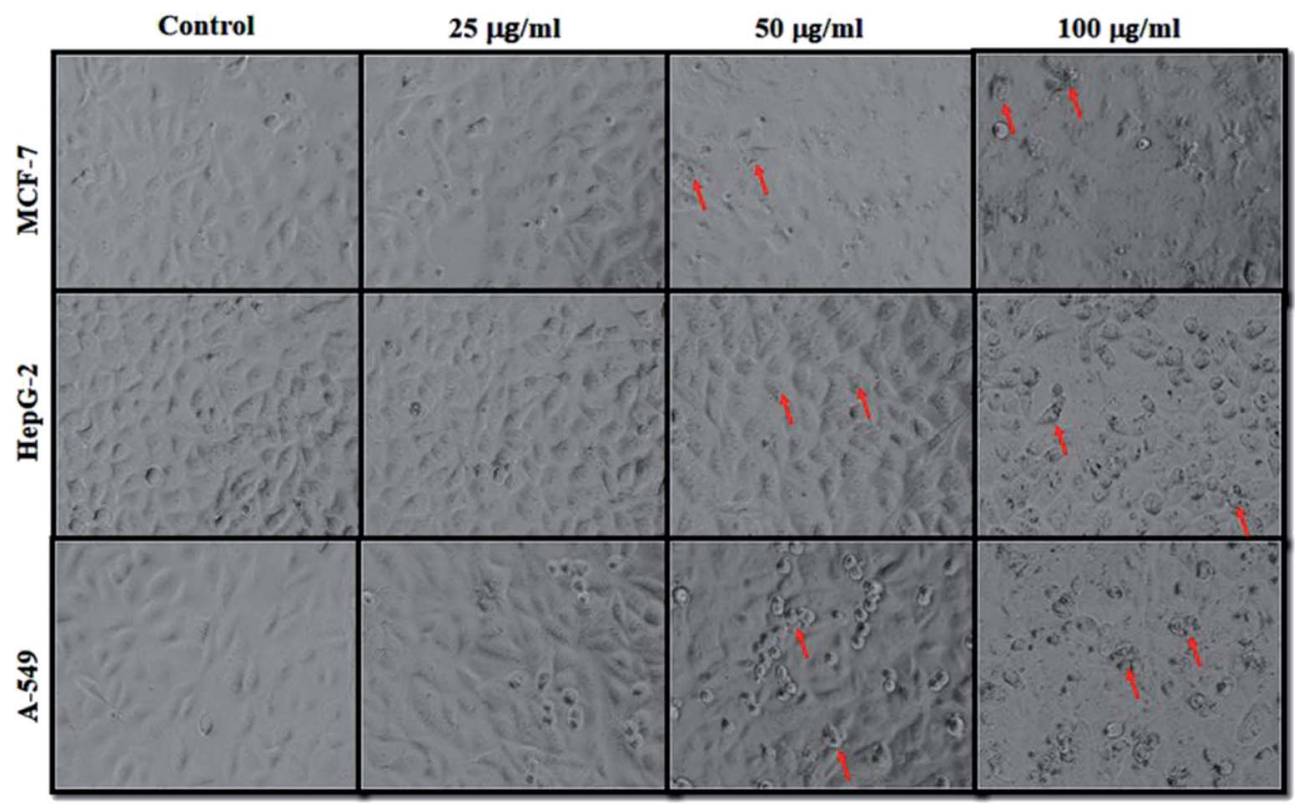

Fig. 3 Change in morphological structure of MCF-7, HepG-2 and A-549 cells following the exposure of variable dose of ZnO nanocrystals for $24 \mathrm{~h}$. Images were captured under the phase contrast inverted microscope at $20 \times$ magnification. $* p<0.05, * * p<0.001$ versus control.

phase contrast microscope. Furthermore, cell viability was determined by MTT assay. ${ }^{59}$ In the mitochondria of living cells, yellow MTT solution is reduced to purple formazan salt. Consequently, DMSO (solubilization buffer solution) is added to dissolve the insoluble purple formazan product into a coloured solution. The cell viability in coloured solution was at $550-570 \mathrm{~nm}$ determined using a spectrophotometer.

The maximum absorption depends on the solvent employed, and the percentage (\%) viability was calculated according to the following equations

$$
\% \text { cell viability }=\left[\frac{(\text { total cells }- \text { viable cells })}{\text { total } \text { cell }}\right] \times 100
$$

or

$$
\% \text { viability }=\left[\frac{\mathrm{OD} \text { in sample well }}{\mathrm{OD} \text { in control }}\right] \times 100
$$

The cancer cells (MCF-7, HepG2, and A549) were treated with different doses of ZnO NPs $\left(1-100 \mu \mathrm{g} \mathrm{m}{ }^{-1}\right)$ for $24 \mathrm{~h}$, and the results are presented in Fig. 4 . We found that the viability of

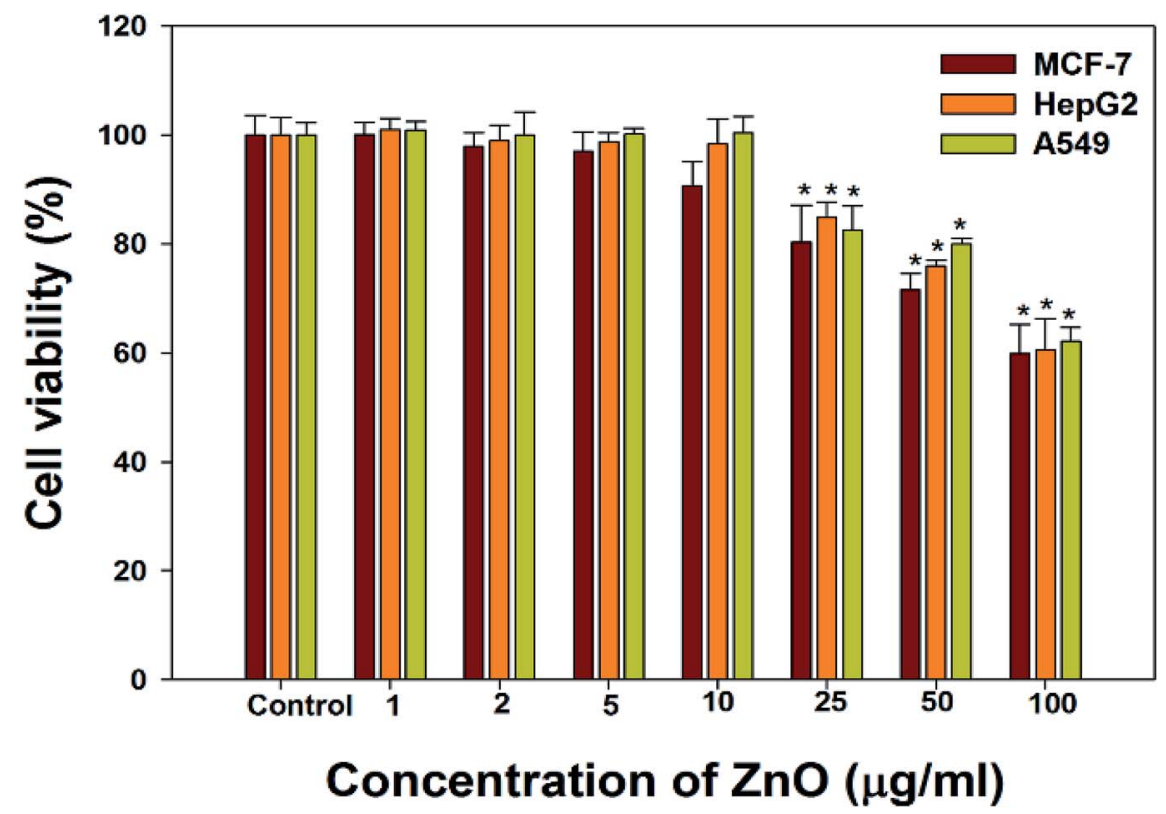

Fig. 4 Cytotoxicity in MCF-7 cells; HepG2 cells; and A549 cell detection by MTT assay. Cells were exposed to different dose (1-100 $\mu \mathrm{g} \mathrm{ml}^{-1}$ ) ZnO for $24 \mathrm{~h}$. Each data values are mean \pm SE of three independent experiments. ${ }^{*} p<0.05, * * p<0.001$ versus control. 
cells decreased with increasing concentrations of ZnO NPs. Cell viability was observed in the range of $80-100 \%$ in after treatment with ZnO NPs ranging from 1-25 $\mu \mathrm{g} \mathrm{ml} \mathrm{m}^{-1}$ in concentration. Conversely, at two higher concentrations, i.e., 50 and 100 $\mu \mathrm{g} \mathrm{ml} \mathrm{m}^{-1}$, the viability of all studied cancer cells was reduced to only $70 \%$ and $60 \%$, respectively (Fig. 4). The observed reductions in cell viability at higher ZnO NP doses were statistically significant $(p<0.05)$.

3.3.2 NRU assay. To support the anticancer study, NRU assay was performed on MCF-7, HepG2 and A549 cells using different doses of ZnO NPs (Fig. 5). The same pattern of cell viability was observed in the NRU assay as in the MTT assay. We observed a statistically significant $(p<0.05)$ decrease in the viability of MCF-7, HepG2, and A549 cancer cells after treatment with 50 and $100 \mu \mathrm{g} \mathrm{ml}^{-1} \mathrm{ZnO}$. At ZnO NP concentrations, less than $50 \mu \mathrm{g} \mathrm{ml}{ }^{-1}$, no significant effect of was observed on the viability of the studied cancer cells.

3.3.3 Effect of biosynthesized ZnO NPs in cancer cell apoptosis determined by flow cytometry. Apoptosis and necrosis are the main mechanisms of cell death. In apoptosis, cells are induced to commit programmed death because of a response to internal or external stimuli, while, in necrosis, the cells are damaged by external injury. Many NPs have been reported to stimulate apoptosis in pre-malignant and malignant cells and hence act as anticancer agents. ${ }^{60,61}$ In the present study, flow cytometry was used to analyse the apoptosis and necrosis of MCF-7, HepG2 and A549 cancer cells after treatment with $100 \mu \mathrm{g} \mathrm{ml}^{-1} \mathrm{ZnO}$ NPs for $48 \mathrm{~h}$ and staining with Annexin V and PI. Fig. 6 indicates a decrease in the viability of cancer cells after treatment with ZnO NPs, with MCF-7, HepG2, and A549 cells showing $60 \%, 62 \%$, and $64 \%$ viability, respectively. Among the MCF-7 cells, $15.5 \%, 16.23 \%$, and $8.27 \%$ were, apoptotic, necrotic and late apoptotic cells respectively, which resulted in approximately $40 \%$ total cell death. HepG2 cells were also exposed to the biosynthesized ZnO NPs for the same time and exhibited approximately $38 \%$ cell death, which was a cumulative result of $10.23 \%$ apoptosis and $22.19 \%$ necrosis followed by

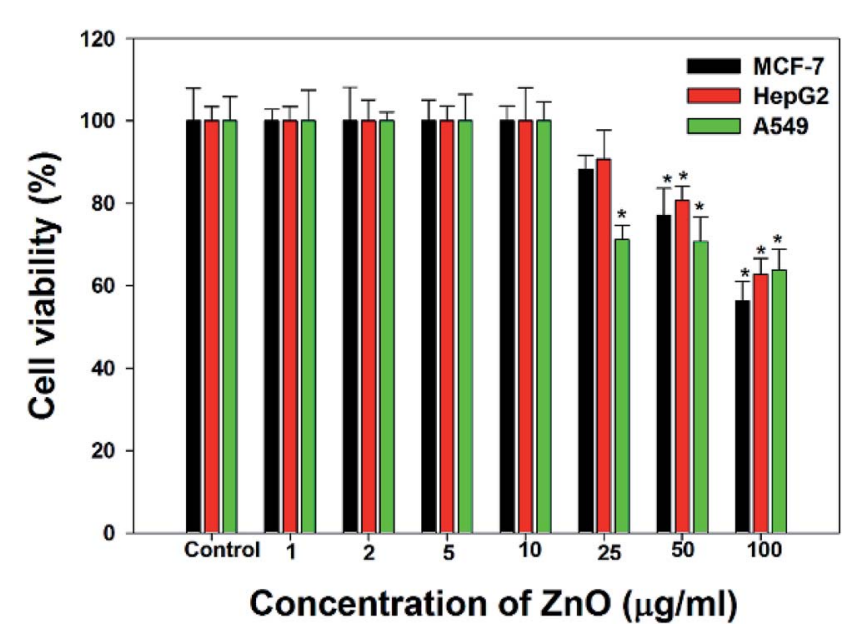

Fig. 5 Cytotoxicity in MCF-7 cells; HepG2 cells; and A549 cells during neutral red uptake (NRU) assay. All the cells were exposed to different dose $\left(1-100 \mu \mathrm{g} \mathrm{ml}^{-1}\right)$ of $\mathrm{ZnO}$ for $24 \mathrm{~h}$. Values are mean \pm SE of three independent experiments. $* p<0.05, * * p<0.001$ versus control.

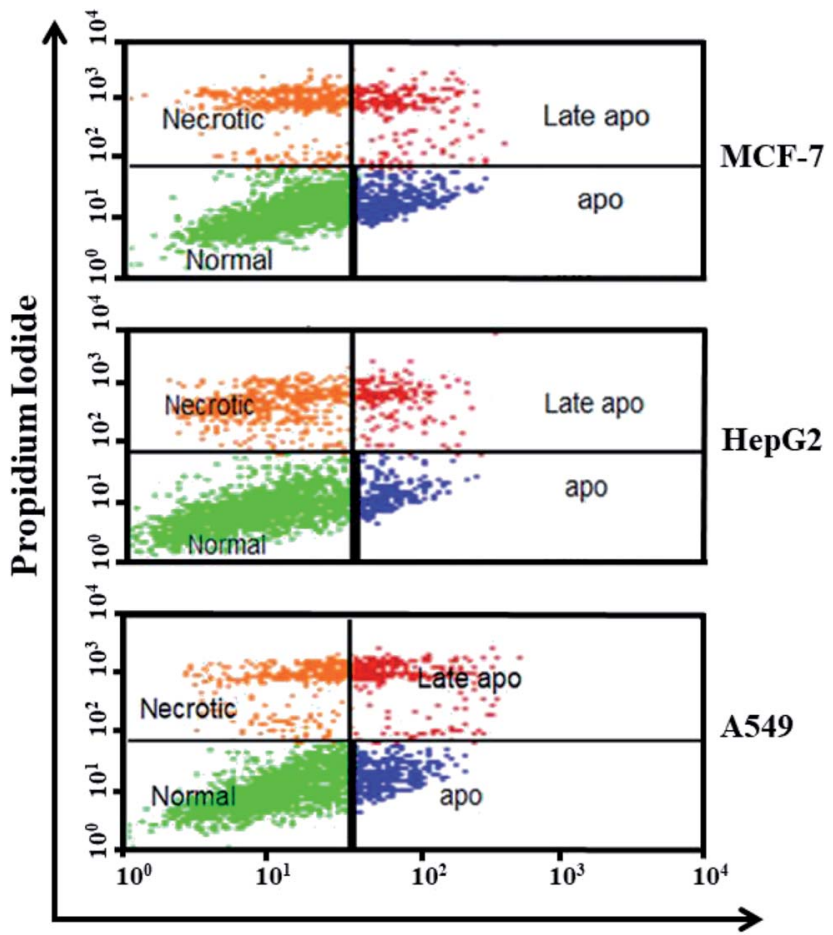

Annexin V-FITC

Fig. 6 The apoptotic effect of biosynthesized ZnO NPs at $100 \mu \mathrm{g} \mathrm{ml}^{-1}$ concentration after $48 \mathrm{~h}$ incubation, using Annexin V-FITC/PI staining of tested MCF-7, HepG2, and A549 cancer cell line. Here dots represent cells as follows: lower right quadrant, early apoptotic cells $\left(\mathrm{FITC}^{+} / \mathrm{PI}^{-}\right)$; lower left quadrant, normal cells $\left(\mathrm{FITC}^{-} / \mathrm{PI}^{-}\right)$; upper right quadrant, late apoptotic cells $\left(\mathrm{FITC}^{+} / \mathrm{PI}^{+}\right)$; upper left quadrant, necrotic cells $\left(\mathrm{FITC}-/ \mathrm{PI}^{+}\right)$.

$6.58 \%$ late apoptosis. The lowest amount of cell death was found in A549 cancer cells, which was 36\%, the sum of $13.12 \%$ apoptotic cells, $14.31 \%$ necrotic cells and $8.67 \%$ late apoptosis. We found that ZnO NPs were the most effective against MCF-7 cells.

Due to the unique biological properties of nanoparticles, it gets a tremendous approach for the treatment of diseases. The anticancer activity of ZnO NPs against human carcinoma cells has already been reported. ${ }^{53}$ In the present study, at higher concentrations of $\mathrm{ZnO} \mathrm{NPs}$, strong anticancer activity was observed. There were no significant morphological changes after treatment with the lower concentrations (1-10 $\left.\mu \mathrm{g} \mathrm{ml}^{-1}\right)$ of ZnO NPs, but the growth of cancer cells decreased with increasing $\mathrm{ZnO} \mathrm{NP}$ doses up to $100 \mu \mathrm{g} \mathrm{m} \mathrm{m}^{-1}$. The cells were damaged at the two highest doses $\left(50 \mu \mathrm{g} \mathrm{ml}^{-1}\right.$ and $\left.100 \mu \mathrm{g} \mathrm{ml}^{-1}\right)$ of NPs (Fig. 3). The typical morphology and adhesion capacity of the treated cells compared to the controls were both reduced at high concentrations of ZnO NPs. The inhibition of MCF-7, HepG2, and A-549 cancer cell growth was found at higher concentrations, i.e., 50 and $100 \mu \mathrm{g} \mathrm{ml}^{-1}$ of biosynthesized $\mathrm{ZnO}$ NPs. This was in close proximity to the findings of Ishwarya et $a l .{ }^{53}$ reported $50 \%$ reduction of MCF-7 breast cancer cells were exhibited at $50 \mu \mathrm{g} \mathrm{ml}^{-1}$ of $\mathrm{ZnO}$ NPs while Selvakumari et $a .^{62}$ who reported that $50 \%$ reduction of human A549 lung cancer cells and MCF-7 breast cancer cells were exhibited at $31.2 \mu \mathrm{g} \mathrm{ml}^{-1}$ of ZnO NPs. At a very low concentration, ZnO NPs 


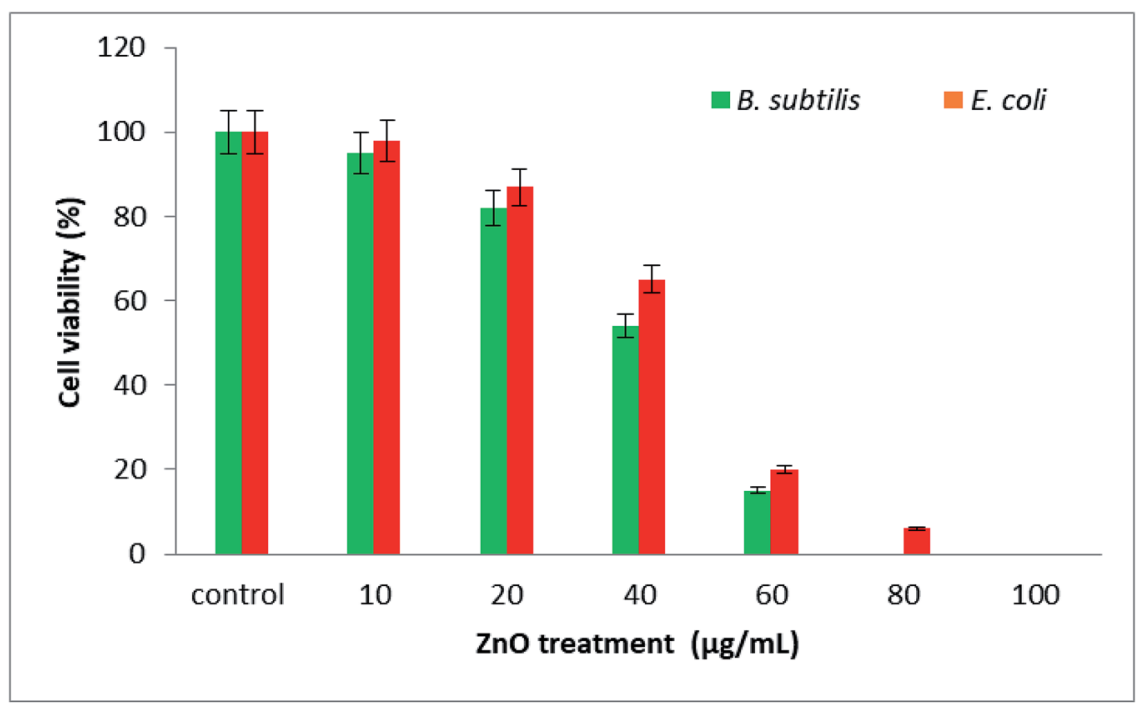

(a

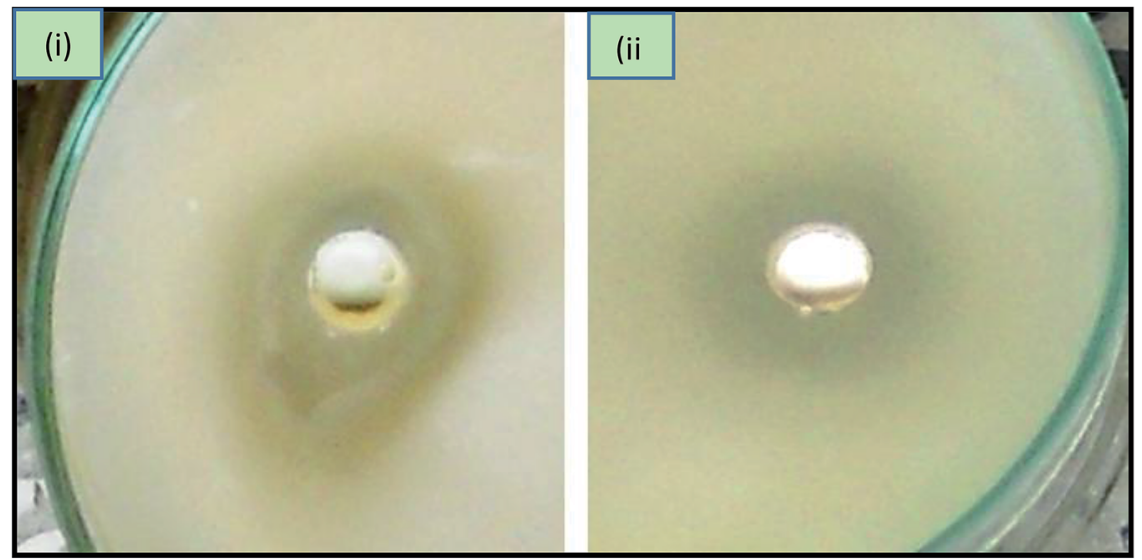

(b

Fig. 7 (a) Effect of ZnO NPs on the growth of Gram-positive (B. subtilis) and Gram-negative (E. coli) bacteria. (b) Zone inhibition image of (i) B. subtilis and (ii) $E$. coli in the presence of biogenic $\mathrm{ZnO}$ loaded in the wells of medium plate.

exhibit activity against liver cancer HepG2 cells in a dosedependent manner. At $25 \mu \mathrm{g} \mathrm{ml}{ }^{-1}$, the viability of HepG2 cells was less than $10 \% .{ }^{63}$ In the present study, a significant reduction in the cell viability in the cancer cells were observed through apoptosis, necrosis and late apoptosis which resulted the decrease in the viability of cancer cells after treatment with ZnO NPs, with MCF-7, HepG2, and A549 cells showing 60\%, $62 \%$, and $64 \%$ viability at $100 \mu \mathrm{g} \mathrm{ml} \mathrm{m}^{-1}$, respectively. These findings are in agreement with Sanaeimehr et al. ${ }^{64}$ who reported the $50 \%$ cell viability at $175 \mu \mathrm{g} \mathrm{m}{ }^{-1}$ in HepG2 cancer cell. Boroumand Moghaddam et al. ${ }^{65}$ found $\mathrm{IC}_{50}$ value was $121 \mu \mathrm{g}$ $\mathrm{ml}^{-1}$ for MCF-7 cells. This suggests that the biosynthesized ZnO NPs have the potential to treat the breast, lung and liver cancer without any harmful effect.

\subsection{Antimicrobial activity}

3.4.1 Bacterial growth inhibition in the presence of $\mathrm{ZnO}$ NPs. The effect of biosynthesized ZnO NPs on the growth of
Gram-positive and Gram-negative bacteria was studied at different concentrations by the broth-dilution method as well as by plating on agar plates. We found that increasing concentrations of ZnO NPs had a significant inhibitory effect on the growth of both bacterial strains (Fig. 7a). However, the bacteriostatic effect was more prominent on the Gram-positive bacterial strain (B. subtilis) than the Gram-negative bacteria strain (E. coli). We observed that $85 \%$ of B. subtilis and $80 \%$ of $E$. coli growth was inhibited by treatment with $60 \mu \mathrm{g} \mathrm{ml} \mathrm{m}^{-1} \mathrm{ZnO}$ NPs. The maximum inhibitory concentration was observed to be $80 \mu \mathrm{g} \mathrm{ml}$; at this concentration, the growth of Gram-positive bacteria completely vanished, while more than $95 \%$ of the growth of Gram-negative bacteria was also inhibited. Minimum inhibitory concentration (MIC) and minimum bactericidal concentration (MBC) of the green synthesized $\mathrm{ZnO}$ NPs ranged from $40-60 \mathrm{~g} \mathrm{ml}^{-1}$ and $80-100 \mathrm{~g} \mathrm{ml}^{-1}$, respectively, against the Gram-positive and Gram-negative bacterial strains. It is significant to note that the growth of both $B$. subtilis and E. coli was 


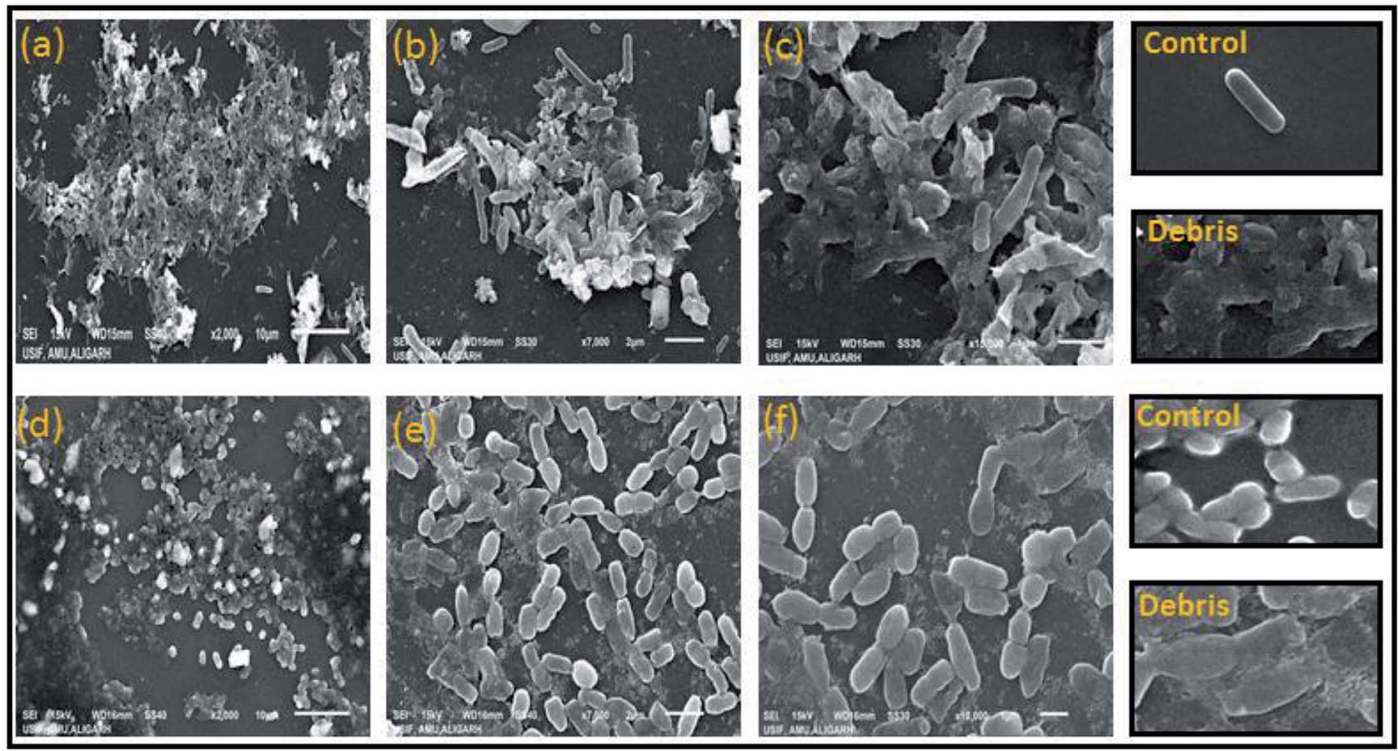

Fig. 8 Scanning electron microscopy imaging at different resolution of partial damage and distorted cells of both bacterial cultures of $E$. coli at $2000 \times$ (a) $7000 \times$ (b) 15000 (c) and B. subtilis at $2000 \times$ (d) $7000 \times$ (e) and $15000 \times$ (f), treated with $75 \mu \mathrm{ml}^{-1} \mathrm{ZnO}$ NPs in growing media and after $8 \mathrm{~h}$ incubation at $37^{\circ} \mathrm{C}$

significantly inhibited by ZnO NPs at least at $40-80 \mu \mathrm{g} \mathrm{ml} \mathrm{m}^{-1}$, which is in agreement with the findings of previous studies on biologically synthesized ZnO NPs. ${ }^{66}$ Similarly, the bactericidal activity of the ZnO NPs against Campylobacter jejuni, Salmonella enterica, and Escherichia coli has been previously reported. ${ }^{67-69}$ The bactericidal effect of the ZnO NPs might be attributed to disruption of the bacterial cell membrane. ${ }^{67}$ Furthermore, it has been observed that the shape and size of NPs also play decisive roles in determining the bactericidal activity of NPs. ${ }^{70}$ Although many studies have reported the biogenic synthesis of ZnO NPs and their antimicrobial activity, this is the first study wherein ZnO NPs were synthesized via a green route involving POLE and their antimicrobial and anticancer activities were explored.

3.4.2 Antibacterial activity of ZnO determined by zone inhibition assay. The biogenic ZnO NPs showed excellent antimicrobial activity against $B$. subtilis and E. coli. Zone inhibition tests were performed on solid nutrient agar media plates. Each plate contained a well loaded with the $\mathrm{ZnO}$ nanomaterial, which diffused into the surrounding media and prevented bacterial growth in a zone around the well. We observed excellent zone inhibition at $26 \mathrm{~nm}$ and $24 \mathrm{~mm}$ against Bacillus subtilis and $E$. coli, respectively, at a biogenic $\mathrm{ZnO}$ concentration of $50 \mu \mathrm{g}$ per well (Fig. 7b). Similarly, in previous studies, inorganic/biogenic $\mathrm{ZnO}$ nanomaterial was also used as an antibacterial agent. ${ }^{66,68}$ During zone inhibition assay, nanomaterials stored in the wells of bacterial culture inoculated plate, here nanomaterials release and diffuse ions into the surrounding media where these ions interact with the inoculated bacteria and significantly prevent the growth of bacteria around the wells and develop a clear halo.

3.4.3 Effect of ZnO NPs on bacterial cell morphology. Previously, we observed that the growth of both Gram-positive and Gram-negative bacteria was inhibited by increasing concentrations of ZnO NPs. We further explored the effect of the ZnO NPs on the cellular morphology of B. subtilis and E. coli by
SEM (Fig. 8). The SEM images of B. subtilis and E. coli exposed to ZnO NPs at a concentration of $50 \mu \mathrm{g} \mathrm{ml}^{-1} \mathrm{ZnO}$ revealed partial damage and distortion of the bacterial cells (Fig. 8). Images were captured at different magnifications ranging from 2000 to $15000 \times$ using a low voltage $(15 \mathrm{kV})$. Fig. 8a-c show E. coli cells, and Fig. 8d-f show B. subtilis cells. It was hypothesized that bacterial cells become stressed in the presence of NPs possibly due to an interaction between the NPs and the bacterial membrane lipid molecules. This interaction may lead to the generation of free radicals, which can damage the membrane transport system and hence further affect bacterial metabolism and growth. In previous studies, researchers have observed that the leakage of protoplasmic inclusions from bacteria is proportional to the amount of interaction with ZnO NPs. ${ }^{71}$ Recently, researchers and drug developers are focusing on biogenic $\mathrm{ZnO}$ nanomaterials manufacturing because of its ease of synthesis and environmentally friendly and effective biomedical application.

\section{Conclusion}

In the present research, we synthesized ZnO NPs from POLE via a green route. The synthesized NPs were characterized by various techniques, including XRD, FESEM, EDX, FTIR and UVvis spectroscopy. We were able to synthesize very pure, spherical ZnO NPs. The focus of this study was to synthesize NPs with anticancer and antimicrobial activities. Hence, the anticancer activity of the synthesized ZnO NPs was evaluated in MCF-7, HepG2, and A549 cells by phase-contrast microscopy and MTT and NRU assays. Furthermore, the anticancer profile of the $\mathrm{ZnO}$ NPs was studied using Annexin V-FITC/PI staining and flow cytometry. The flow cytometry results indicated that apoptosis, necrosis and late apoptosis were the main causes of cell death. These biosynthesized ZnO NPs were significantly effective 
against the studied cancer cell lines. Additionally, the antimicrobial activity of the ZnO NPs was confirmed in Gram-positive (Bacillus subtilis) and Gram-negative (Escherichia coli) bacteria. Overall, the results of this study establish that the biogenic synthesis of ZnO NPs from POLE leads to the formation of very pure, spherical NPs with anticancer and antimicrobial properties. These NPs have the potential for development into promising chemotherapeutic treatments for cancer and bacterial multidrug resistance but require further investigation.

\section{Conflicts of interest}

There is no conflict of interest.

\section{Acknowledgements}

The authors extend their appreciation to the International Scientific Partnership Program (ISPP) at King Saud University for funding this research work through (ISPP-126).

\section{References}

1 A Detail Investigation to Observe the Effect of Zinc Oxide |Nanoparticle| Zinc Oxide, 2019. Available from: https:// www.scribd.com/document/89002172/A-DetailInvestigation-to-Observe-the-Effect-of-Zinc-Oxide.

2 S. Sahoo, Socio-ethical issues and nanotechnology development: Perspectives from India, 10th IEEE International Conference on Nanotechnology, IEEE, 2010 , pp. 1205-10. Available from: http://ieeexplore.ieee.org/ document/5697887/.

3 D. Bhattacharyya, S. Singh, N. Satnalika, A. Khandelwal, S.-H. Jeon, Nanotechnology, Big things from a Tiny World: a Review, International Journal of u-and e-Service, 2009, Vol. 2. Available from: https://www.ida.liu.se/ T TGTU51/ articles/MPN-paper.pdf.

4 S. Pal, Y. K. Tak and J. M. Song, Does the antibacterial activity of silver nanoparticles depend on the shape of the nanoparticle? A study of the Gram-negative bacterium Escherichia coli, Appl. Environ. Microbiol., 2007, 73(6), 1712-1720.

5 C. Balachandran, S. N. Ramasamy and L. Palanikumar, Sizedependent antimicrobial response of zinc oxide nanoparticles, IET Nanobiotechnol., 2014, 8(2), 111-117.

6 J. W. Rasmussen, E. Martinez, P. Louka and D. G. Wingett, Zinc oxide nanoparticles for selective destruction of tumor cells and potential for drug delivery applications, Expert Opin. Drug Deliv., 2010, 7(9), 1063-1077.

7 H. Zhang, B. Chen, H. Jiang, C. Wang, H. Wang and X. Wang, A strategy for $\mathrm{ZnO}$ nanorod mediated multi-mode cancer treatment, Biomaterials, 2011, 32(7), 1906-1914.

8 M. Ramani, S. Ponnusamy, C. Muthamizhchelvan and E. Marsili, Amino acid-mediated synthesis of zinc oxide nanostructures and evaluation of their facet-dependent antimicrobial activity, Colloids Surf., B, 2014, 117, 233-239.

9 WHO, Cancer control: knowledge into action, WHO, 2012. Available from: https://www.who.int/cancer/modules/en/.
10 I. Ali, L. Naim, A. Ghanem and H. Y. Aboul-Enein, Chiral separations of piperidine-2,6-dione analogues on Chiralpak IA and Chiralpak IB columns by using HPLC, Talanta, 2006, 69, 1013-1017.

11 I. Ali, M. M. Sanagi and H. Y. Aboul-Enein, Advances in chiral separations by non-aqueous capillary electrophoresis in pharmaceutical and biomedical analysis, Electrophoresis, 2014, 35, 926-936.

12 I. Ali, V. K. Gupta, Encyclopedioa of surface and colloid sciences, Marcel \& Dekker Inc., New York, 2002, pp. 136-166.

13 K. Sikora, S. Advani, V. Koroltchouk, I. Magrath, L. Levy, H. Pinedo, et al., Essential drugs for cancer therapy: a World Health Organization consultation, Ann. Oncol., 1999, 10(4), 385-390.

14 I. Ali, M. Asim and T. A. Khan, Arsenic removal from water by electrocoagulation on zinc-zinc and copper-copper electrodes, Int. J. Environ. Sci. Technol., 2013, 10, 377-384.

15 P. S. Tourinho, C. A. M. van Gestel, S. Lofts, C. Svendsen, A. M. V. M. Soares and S. Loureiro, Metal-based nanoparticles in soil: Fate, behavior, and effects on soil invertebrates, Environ. Toxicol. Chem., 2012, 31(8), 16791692.

16 Z. P. Xu, Q. H. Zeng, G. Q. Lu and A. B. Yu, Inorganic nanoparticles as carriers for efficient cellular delivery, Chem. Eng. Sci., 2006, 61(3), 1027-1040.

17 K. K. Y. Wong and X. L. Liu, Nanomedicine: a primer for surgeons, Pediatr. Surg. Int., 2012, 28(10), 943-951.

18 C. Hanley, J. Layne, A. Punnoose, K. M. Reddy, I. Coombs, A. Coombs, et al., Preferential killing of cancer cells and activated human $\mathrm{T}$ cells using ZnO nanoparticles, Nanotechnology, 2008, 19(29), 295103.

19 H. Wang, D. Wingett, M. H. Engelhard, K. Feris, K. M. Reddy, P. Turner, et al., Fluorescent dye encapsulated $\mathrm{ZnO}$ particles with cell-specific toxicity for potential use in biomedical applications, J. Mater. Sci. Mater. Med., 2009, 20(1), 11-22.

20 J. Sawai, S. Shoji, H. Igarashi, A. Hashimoto, T. Kokugan, M. Shimizu, et al., Hydrogen peroxide as an antibacterial factor in zinc oxide powder slurry, J. Ferment. Bioeng., 1998, 86(5), 521-522.

21 M. Faheem, M. T. Rehman, M. Danishuddin and A. U. Khan, Biochemical Characterization of CTX-M-15 from Enterobacter cloacae and Designing a Novel Non- $\beta$-Lactam$\beta$-Lactamase Inhibitor, PLoS One, 2013, 8(2), e56926.

22 A. U. Khan and M. T. Rehman, Role of Non-Active-Site Residue Trp-93 in the Function and Stability of New Delhi Metallo- $\beta$-Lactamase 1, Antimicrob. Agents Chemother., 2016, 60(1), 356-360.

23 G. Muteeb, M. Rehman, S. Ali, A. Al-Shahrani, M. Kamal and G. Ashraf, Phage Display Technique: A Novel Medicinal Approach to Overcome An tibiotic Resistance by Using Peptide-Based Inhibitors Against $\beta$-Lactamases, Curr. Drug Metab., 2017, 18(2), 90-95.

24 K. L. Kotloff, J. P. Winickoff, B. Ivanoff, J. D. Clemens, D. L. Swerdlow, P. J. Sansonetti, et al., Global burden of Shigella infections: implications for vaccine development and implementation of control strategies, Bull. World Health Organ., 1999, 77(8), 651-666. 
25 K. M. Reddy, K. Feris, J. Bell, D. G. Wingett, C. Hanley and A. Punnoose, Selective toxicity of zinc oxide nanoparticles to prokaryotic and eukaryotic systems, Appl. Phys. Lett., 2007, 90, 213902.

26 K. Kasemets, A. Ivask, H.-C. Dubourguier and A. Kahru, Toxicity of nanoparticles of $\mathrm{ZnO}, \mathrm{CuO}$ and $\mathrm{TiO} 2$ to yeast Saccharomyces cerevisiae, Toxicol. Vitro, 2009, 23(6), 11161122.

27 A. Lipovsky, Y. Nitzan, A. Gedanken and R. Lubart, Antifungal activity of $\mathrm{ZnO}$ nanoparticles - the role of ROS mediated cell injury, Nanotechnology, 2011, 22(10), 105101.

28 R. Jalal, E. K. Goharshadi, M. Abareshi, M. Moosavi, A. Yousefi and P. Nancarrow, ZnO nanofluids: Green synthesis, characterization, and antibacterial activity, Mater. Chem. Phys., 2010, 121(1-2), 198-201.

29 M. Ramani, S. Ponnusamy and C. Muthamizhchelvan, From zinc oxide nanoparticles to microflowers: A study of growth kinetics and biocidal activity, Mater. Sci. Eng. C, 2012, 32(8), 2381-2389.

30 S. S. Kumar, P. Venkateswarlu, V. R. Rao and G. N. Rao, Synthesis, characterization and optical properties of zinc oxide nanoparticles, Int. Nano Lett., 2013, 3(1), 30.

31 A. Stanković, S. Dimitrijević and D. Uskoković, Influence of size scale and morphology on antibacterial properties of ZnO powders hydrothemally synthesized using different surface stabilizing agents, Colloids Surf., B, 2013, 102, 21-28.

32 N. Talebian, S. M. Amininezhad and M. Doudi, Controllable synthesis of $\mathrm{ZnO}$ nanoparticles and their morphologydependent antibacterial and optical properties, $J$. Photochem. Photobiol., B, 2013, 120, 66-73.

33 J. Ma, J. Liu, Y. Bao, Z. Zhu, X. Wang and J. Zhang, Synthesis of large-scale uniform mulberry-like $\mathrm{ZnO}$ particles with microwave hydrothermal method and its antibacterial property, Ceram. Int., 2013, 39(3), 2803-2810.

34 E. E. Hafez, H. S. Hassan, M. F. Elkady and E. Salama, Assessment Of Antibacterial Activity For Synthesized Zinc Oxide Nanorods Against Plant Pathogenic Strains, Int. J. Sci. Technol. Res., 2014, 3(9), 318-324.

35 N. Ain Samat and R. Md Nor, Sol-gel synthesis of zinc oxide nanoparticles using Citrus aurantifolia extracts, Ceram. Int., 2013, 39, S545-S548.

36 P. Rajiv, S. Rajeshwari and R. Venckatesh, Bio-Fabrication of zinc oxide nanoparticles using leaf extract of Parthenium hysterophorus L. and its size-dependent antifungal activity against plant fungal pathogens, Spectrochim. Acta, Part A, 2013, 112, 384-387.

37 S. Gunalan, R. Sivaraj and V. Rajendran, Green synthesized $\mathrm{ZnO}$ nanoparticles against bacterial and fungal pathogens, Prog. Nat. Sci.: Mater. Int., 2012, 22(6), 693-700.

38 P. P. Adkar and V. H. Bhaskar, Pandanus odoratissimus (Kewda): A Review on Ethnopharmacology, Phytochemistry, and Nutritional Aspects, Adv. Pharmacol. Sci., 2014, 2014, 1-19.

39 S. Iravani, Green synthesis of metal nanoparticles using plants, Green Chem., 2011, 13(10), 2638.
40 Y. A. Mirgorod and V. G. Borodina, Preparation and bactericidal properties of silver nanoparticles in aqueous tea leaf extract, Inorg. Mater., 2013, 49(10), 980-983.

41 Y. A. Mirgorod, V. G. Borodina and N. A. Borsch, Investigation of interaction between silver ions and rutin in water by physical methods, Biophysics, 2013, 58(6), 743747.

42 M. F. Alajmi, J. Ahmed, A. Hussain, T. Ahamad, N. Alhokbany, S. Amir, et al., Green synthesis of Fe3O4 nanoparticles using aqueous extracts of Pandanus odoratissimus leaves for efficient bifunctional electrocatalytic activity, Appl. Nanosci., 2018, 8(6), 1427-1435.

43 M. Arab, B. Bahramian, A. Schindeler, A. Fathi, P. Valtchev, R. McConchie, et al., A benign process for the recovery of solanesol from tomato leaf waste, Heliyon, 2019, 5(4), e01523.

44 A. Luximon-Ramma, T. Bahorun, M. A. Soobrattee and O. I. Aruoma, Antioxidant activities of phenolic, proanthocyanidin, and flavonoid components in extracts of Cassia fistula, J. Agric. Food Chem., 2002, 50(18), 5042-5047.

45 S. Ghosh, S. Patil, M. Ahire, R. Kitture, S. Kale, K. Pardesi, S. S. Cameotra, J. Bellare, D. D. Dhavale, A. Jabgunde and B. A. Chopade, Synthesis of silver nanoparticles using Dioscorea bulbifera tuber extract and evaluation of its synergistic potential in combination with antimicrobial agents, Int. J. Nanomed., 2012, 7, 483-496.

46 A. B. Pant, A. K. Agarwal, V. P. Sharma and P. K. Seth, In vitro cytotoxicity evaluation of plastic biomedical devices, Hum. Exp. Toxicol., 2001, 20(8), 412-417.

47 M. A. Siddiqui, G. Singh, M. P. Kashyap, V. K. Khanna, S. Yadav, D. Chandra, et al., Influence of cytotoxic doses of 4-hydroxynonenal on selected neurotransmitter receptors in PC-12 cells, Toxicol. Vitro, 2008, 22(7), 1681-1688.

48 M. A. Siddiqui, M. P. Kashyap, V. Kumar, A. A. Al-Khedhairy, J. Musarrat and A. B. Pant, Protective potential of transresveratrol against 4-hydroxynonenal induced damage in PC12 cells, Toxicol. Vitro, 2010, 24(6), 1592-1598.

49 J. A. Marchal, H. Boulaiz, I. Suárez, E. Saniger, J. Campos, E. Carrillo, et al., Growth inhibition, G 1 -arrest, and apoptosis in MCF-7 human breast cancer cells by novel highly lipophilic 5-fluorouracil derivatives, Invest. New Drugs, 2004, 22(4), 379-389.

50 M. Awwad A, M. Salem N and O. Abdeen A, Biosynthesis of Silver Nanoparticles using Olea europaea Leaves Extract and its Antibacterial Activity, Nanosci. Nanotechnol., 2013, 2(6), 164-170.

51 S. Mukherjee, V. Sushma, S. Patra, A. K. Barui, M. P. Bhadra, B. Sreedhar, et al., Green chemistry approach for the synthesis and stabilization of biocompatible gold nanoparticles and their potential applications in cancer therapy, Nanotechnology, 2012, 23(45), 455103.

52 S. Vijayakumar, G. Vinoj, B. Malaikozhundan, S. Shanthi and B. Vaseeharan, Plectranthus amboinicus leaf extract mediated synthesis of zinc oxide nanoparticles and its control of methicillin resistant Staphylococcus aureus biofilm and blood sucking mosquito larvae, Spectrochim. Acta, Part A, 2015, 137, 886-891. 
53 R. Ishwarya, B. Vaseeharan, S. Kalyani, B. Banumathi, M. Govindarajan, N. S. Alharbi, et al., Facile green synthesis of zinc oxide nanoparticles using Ulva lactuca seaweed extract and evaluation of their photocatalytic, antibiofilm and insecticidal activity, J. Photochem. Photobiol., B, 2018, 178, 249-258.

54 S. Narendhran and R. Sivaraj, Biogenic ZnO nanoparticles synthesized using L. aculeata leaf extract and their antifungal activity against plant fungal pathogens, Bull. Mater. Sci., 2016, 39(1), 1-5.

55 P. Vanathi, P. Rajiv, S. Narendhran, S. Rajeshwari, P. K. S. M. Rahman and R. Venckatesh, Biosynthesis and characterization of phyto mediated zinc oxide nanoparticles: A green chemistry approach, Mater. Lett., 2014, 134, 13-15.

56 R. Wahab, S. G. Ansari, Y.-S. Kim, H.-K. Seo and H.-S. Shin, Room temperature synthesis of needle-shaped $\mathrm{ZnO}$ nanorods via sonochemical method, Appl. Surf. Sci., 2007, 253(18), 7622-7626.

57 M. F. Al-Ajmi, A. Hussain, E. Alsharaeh, F. Ahmed, S. Amir, M. S. Anwar, et al., Green Synthesis of Zinc Oxide Nanoparticles Using Alstonia Macrophylla Leaf Extract and Their In-Vitro Anticancer Activity, Sci. Adv. Mater., 2018, 10(3), 349-355.

58 R. F. Silva and M. E. Zaniquelli, Morphology of nanometric size particulate aluminium-doped zinc oxide films, Colloids Surf., A, 2002, 198-200, 551-558.

59 T. Mosmann, Rapid colorimetric assay for cellular growth and survival: application to proliferation and cytotoxicity assays, J. Immunol. Methods, 1983, 65(1-2), 55-63.

60 Y. Bendale, V. Bendale and S. Paul, Evaluation of cytotoxic activity of platinum nanoparticles against normal and cancer cells and its anticancer potential through induction of apoptosis, Integr. Med. Res., 2017, 6(2), 141-148.

61 A. P. Bidkar, P. Sanpui and S. S. Ghosh, Efficient induction of apoptosis in cancer cells by paclitaxel-loaded selenium nanoparticles, Nanomedicine, 2017, 12(21), 2641-2651.

62 D. Selvakumari, R. Deepa, V. Mahalakshmi, P. Subhashini and N. Lakshminarayan, Anti Cancer Activity of $\mathrm{ZnO}$ Nanoparticles on MCF7 (Breast Cancer Cell) and A549
(Lung Cancer Cell), ARPN J. Eng. Appl. Sci., 2015, 10(12), 5418-5421.

63 M. Vinardell and M. Mitjans, Antitumor Activities of Metal Oxide Nanoparticles, Nanomaterials, 2015, 5(2), 1004-1021.

64 Z. Sanaeimehr, I. Javadi and F. Namvar, Antiangiogenic and antiapoptotic effects of green-synthesized zinc oxide nanoparticles using Sargassum muticum algae extraction, Cancer Nanotechnol., 2018, 9(1), 3.

65 A. Boroumand Moghaddam, M. Moniri, S. Azizi, R. Abdul Rahim, A. Bin Ariff, M. Navaderi, et al., Eco-Friendly Formulated Zinc Oxide Nanoparticles: Induction of Cell Cycle Arrest and Apoptosis in the MCF-7 Cancer Cell Line, Genes, 2017, 8(10), 1-15.

66 N. A. Al-Shabib, F. M. Husain, I. Hassan, M. S. Khan, F. Ahmed, F. A. Qais, et al., Biofabrication of Zinc Oxide Nanoparticle from Ochradenus baccatus Leaves: BroadSpectrum Antibiofilm Activity, Protein Binding Studies, and In Vivo Toxicity and Stress Studies, J. Nanomater., 2018, 2018, 1-14.

67 Y. Xie, Y. He, P. L. Irwin, T. Jin and X. Shi, Antibacterial Activity and Mechanism of Action of Zinc Oxide Nanoparticles against Campylobacter jejuni, Appl. Environ. Microbiol., 2011, 77(7), 2325-2331.

68 A. Azam, A. S. Ahmed, M. Oves, M. S. Khan, S. S. Habib and A. Memic, Antimicrobial activity of metal oxide nanoparticles against Gram-positive and Gram-negative bacteria: a comparative study, Int. J. Nanomed., 2012, 7, 6003.

69 M. Oves, M. Arshad, M. S. Khan, A. S. Ahmed, A. Azam and I. M. I. Ismail, Anti-microbial activity of cobalt doped zinc oxide nanoparticles: Targeting water borne bacteria, $J$. Saudi Chem. Soc., 2015, 19(5), 581-588.

70 A. Azam, A. S. Ahmed, M. Oves, M. S. Khan and A. Memic, Size-dependent antimicrobial properties of $\mathrm{CuO}$ nanoparticles against Gram-positive and -negative bacterial strains, Int. J. Nanomed., 2012, 7, 3527.

71 L. S. Reddy, M. M. Nisha, M. Joice and P. N. Shilpa, Antimicrobial activity of zinc oxide ( $\mathrm{ZnO})$ nanoparticle against Klebsiella pneumoniae, Pharm. Biol., 2014, 52(11), 1388-1397. 